Note

\title{
Phaeohyphomycosis caused by Alternaria infectoria presenting as multiple vegetating lesions in a renal transplant patient
}

\author{
Daniela Cunha a,*, Cristina Amaro ${ }^{\mathrm{a}}$, María Raquel Vieira ${ }^{\mathrm{a}}$, María da Luz Martins ${ }^{\mathrm{b}}$, Ana Paula Maduro ${ }^{\mathrm{b}}$, \\ João Inácio ${ }^{c}$, Ana Afonso ${ }^{\mathrm{d}}$, Gabriela Marques Pinto ${ }^{\mathrm{a}}$, Jorge Cardoso ${ }^{\mathrm{a}}$ \\ a Dermatology Department, Hospital de Curry Cabral, Lisbon, Portugal \\ ${ }^{\mathrm{b}}$ Mycology Laboratory, Instituto de Higiene e Medicina Tropical/CREM, Universidade Nova de Lisboa, Lisbon, Portugal \\ ${ }^{\mathrm{c}}$ Laboratório Nacional de Investigação Veterinária, Instituto Nacional de Recursos Biológicos, Lisbon, Portugal \\ ${ }^{\mathrm{d}}$ Histopathology Department, Hospital de Curry Cabral, Lisbon, Portugal
}

\section{A R T I C L E I N F O}

Article history:

Received 1 December 2010

Accepted 22 June 2011

Available online 7 July 2011

\section{Keywords:}

Mycosis

Kidney transplantation

Itraconazole

Immunocompromised patient

\begin{abstract}
A B S T R A C T
The genus Alternaria is one of the most common black moulds and appears to be increasing as a causative agent of subcutaneous phaeohyphomycosis, particularly among immunosuppressed patients.

A 53-year-old patient who had received a kidney transplant presented with multiple verrucous lesions on the distal extremities. Positive histopathology and cultures, in addition to rDNA ITS region sequencing, identified the fungal isolate as Alternaria infectoria. Oral itraconazole was administered for 10 months. A follow-up at 15 months demonstrated no signs of infection.

Clinical manifestations of cutaneous alternariosis vary significantly and only a few cases have been described in the literature. Although optimal treatment options remain controversial, this case of phaeohyphomycosis was successfully treated with itraconazole monotherapy.
\end{abstract}

(c) 2010 Revista Iberoamericana de Micología. Published by Elsevier España, S.L. All rights reserved.

\section{Feohifomicosis producida por Alternaria infectoria con presentación clínica de múltiples lesiones vegetantes en un paciente sometido a un trasplante renal}

\section{R E S U M E N}

Las especies del género Alternaria son mohos ubicuos que se caracterizan por presentar colonias de color gris; parecen ser cada vez más frecuentes como agente causal de las feohifomicosis subcutáneas, en especial entre pacientes inmunocomprometidos.

Un paciente de 53 años de edad, que se había sometido a un trasplante renal, consultó por presentar tumores verrugosos en el tercio distal de las extremidades. La histopatología y cultivo positivos, además de la secuenciación de la región de transcripción interna ITS del rDNA, permitieron la identificación del aislamiento fúngico como Alternaria infectoria. Se instauró tratamiento con itraconazol oral durante 10 meses y, a los 15 meses de seguimiento, se demostró la ausencia de signos de infección.

Las manifestaciones clínicas de la alternariosis cutánea son muy variables y tan sólo se han descrito unos pocos casos en los que se presenta en forma de tumoraciones verrugosas. Aunque el tratamiento de elección sigue siendo motivo de controversia, el paciente presentado en este estudio fue tratado satisfactoriamente con itraconazol.

(c) 2010 Revista Iberoamericana de Micología. Publicado por Elsevier España, S.L. Todos los derechos reservados.
Subcutaneous phaeohyphomycosis is an infection caused by an heterogeneous group of dematiaceous fungi. ${ }^{15}$ Infections by species of Alternaria accounted for a significant number of cases

\footnotetext{
* Corresponding author.

E-mail address: danielaccunha@gmail.com (D. Cunha).
}

reported in recent years. ${ }^{2,3,5,6,9,11,12,14,16,18}$ Members of this genus are generally found in aerosols, in soil, or on plants, and are typically pathogenic only to immunocompromised hosts. $2,3,5,6,8-16,18$ Nevertheless, a few reports describing cutaneous infections among immunocompetent individuals have also been described. ${ }^{17}$

The development and refinement of modern molecular biologic techniques have lead to a better genotypic characterization 


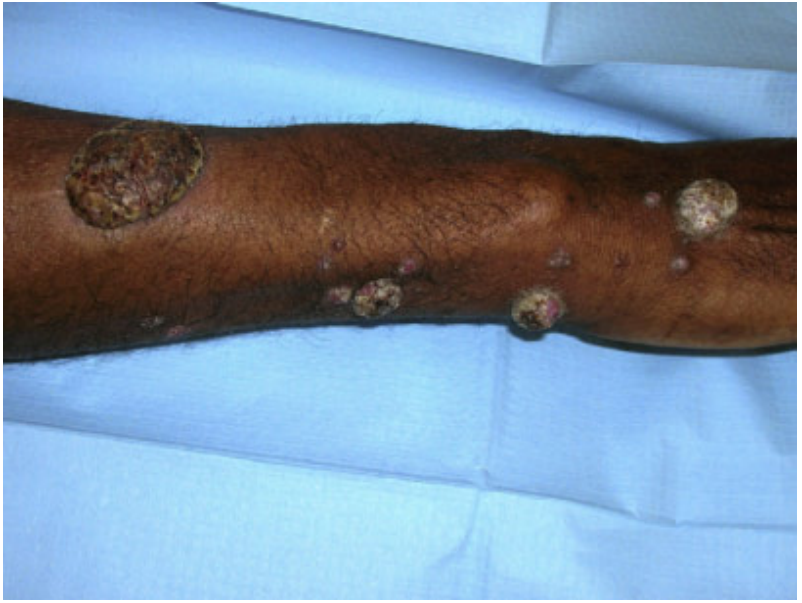

Figure 1. Widespread verrucous hyperkeratotic tumours.

of dematiaceous species associated with phaeohyphomycosis, resulting in a better understanding of these infections over the past decade.

\section{Case report}

A 53-year-old male gardener presented with multiple asymptomatic vegetating hyperkeratotic lesions and nodules on the distal extremities that had evolved over the past two months. There was no previous history of skin lesions or trauma. The patient had undergone kidney transplantation 16 months previously, due to end-stage renal disease of unknown etiology. Since transplantation, the patient was treated with tacrolimus plus mofetil mycophenolate and prednisolone and, at presentation, the dosages were $6 \mathrm{mg}$ bid, $750 \mathrm{mg}$ bid and $10 \mathrm{mg}$ o.d., respectively.

On examination, there were widespread, multiple keratotic and vegetating tumours, as well as several purplish non-painful nodules on the forearms, dorsum of the hands and shins. Lesions varied in size but a few reached $3.0 \mathrm{~cm}$ in diameter (Fig. 1). There was no edema or lymphadenopathy and vital signs were normal. The patient was treated with itraconazole $400 \mathrm{mg}$ o.d. for 10 months and the tacrolimus dose was adjusted accordingly. Complete resolution of skin lesions was achieved 9 months after treatment and itraconazole was administered for 4 weeks more. There was no recurrence 15 months after completion of the treatment.

Routine laboratory tests, including renal function and chest radiography, were unremarkable. Histopathology of the skin biopsy showed a granulomatous infiltrate with septate hyphae and oval-shaped structures following periodic acid-Schiff and Grocott's staining (Fig. 2). Direct examination of portions of the biopsy performed with $20 \%$ potassium hydroxide solution revealed several hyaline septate hyphae. For isolation, the remainder of the biopsy was inoculated onto Sabouraud dextrose agar, Brain-heartinfusion agar and Malt agar (DIFCO ${ }^{\circledR}$, Detroit, USA) and incubated at $24^{\circ} \mathrm{C}$ and $37^{\circ} \mathrm{C}$. After seven days incubation, fungal colonies were discernable on the respective media. By day 21 , the surface of the colonies was gray-white and cottony and the reverse was dark-brown. Microscopic examination revealed septate, brown hyphae with simple or branched conidiophores and multiple conidia. Conidia were mainly ovoid but some were muriform, smooth walled or verrucous, and a few ended with apical beaks, most forming acropetal chains (Fig. 3). After DNA extraction, the ITS (internal transcribed spacer) region of rDNA was PCR-amplified and sequencing of the ITS region was carried out using forward primer ITS1 and reverse primer ITS4 following standard protocols (STAB Vida Lda, Caparica, Portugal). The nucleotide sequence was

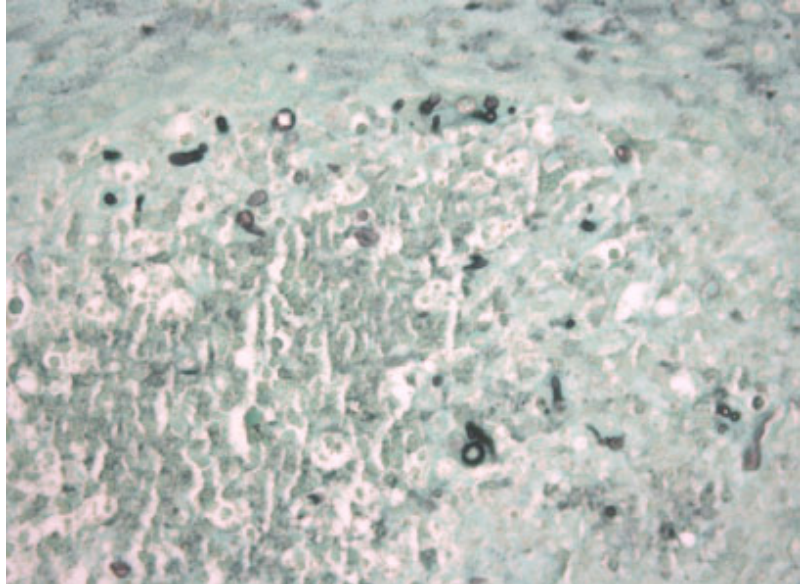

Figure 2. Histopathological examination with Grocott's stain (magnification $\times 400$ ).

deposited in GenBank with the accession number HM467255. Standard BLAST searches at GenBank database revealed a high similarity between this sequence and others representing Alternaria species (which are assigned in GenBank as Lewia, the designation of the respective teleomorphs). A phylogenetic tree was computed using PAUP software (Sinauer Associates, Inc., Sunderland, MA), including ITS sequences belonging to reference strains of Alternaria species, and to other closely related fungi, retrieved from GenBank (data not shown). This phylogenetic analysis placed our fungal isolate in the Alternaria infectoria species-group ${ }^{1}$ and the $99.6 \%$ nucleotide identity with the type strain of A. infectoria, CBS $112250^{\mathrm{T}}$, further classified the isolate as this species.

\section{Discussion}

Cutaneous infections caused by Alternaria spp. were rarely reported prior to the use of highly potent immunosuppressive drugs in solid organ transplantation. These types of infections, however, are likely to become more frequent as the number of patients on these drug therapies and their survival time increase. Infections in patients with underlying immunosuppressive disease, such as diabetes mellitus, Cushing's syndrome, or haematological cancers have also been reported. ${ }^{8,10,13}$ Among the Alternaria species responsible for opportunistic infections in organ recipient patients, A. infectoria accounts for only a minority of cases reported over the past decade. ${ }^{2,3,5,6,9,11,12,14,16,18}$

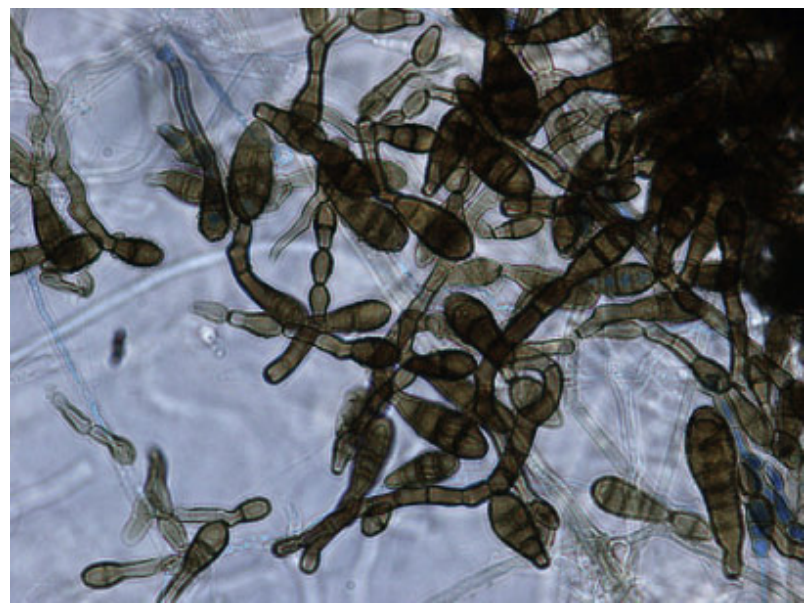

Figure 3. Microscopic examination following lactophenol blue staining (magnification $\times 1500)$. 
The spectrum of cutaneous manifestations resulting from alternariosis is broad and includes papules, tumours, and ulcerating lesions. There is no correlation between any given presentation and a specific causal agent among Alternaria species. Nevertheless, the great majority of the reported cutaneous infections caused by $A$. infectoria presented as asymptomatic nodules distributed at the extremities. $2,3,5,6,12,18$ The anatomic distribution of the lesions seems to result from direct inoculation of the fungus into damaged skin following contact with a contaminated fomite or plant. ${ }^{4}$

As A. infectoria is a common saprophyte prevalent in the environment inhabiting primarily leaves and kernels of grasses and cereals, ${ }^{14}$ fungi may be present at the superficial epidermal layers of human skin, representing environmental contaminants. Therefore, when phaeohyphomycosis is suspected, a deep tissue sample should be obtained for isolation and identification of the fungus. ${ }^{4}$ The morphological findings of cutaneous alternariosis include dermal granulomatous infiltrates with variable epidermal changes. Fungal elements are usually seen within these infiltrates, presenting as spheroidal chlamydospore-like structures and hyphae, with and without pigmentation.,7 Fungal culture on Sabouraud agar without cycloheximide yields "greyish", "green, powdery" or "felty" colonies. By lactophenol cotton blue staining, the microscopic observation of pigmented conidiophores giving rise to dictyospores is highly suggestive of $A$. infectoria. The apical growth of long geniculate secondary conidiophores is a typical feature of the $A$. infectoria species-group.

Molecular studies may provide additional time-efficient diagnostic information. Comparative analysis of rDNA ITS nucleotide sequences is commonly used for the identification of fungal species, ${ }^{4}$ including Alternaria spp. ${ }^{12,14,16}$ This approach led to a rapid and accurate identification of the isolate described in this report that was otherwise difficult to identify using traditional culture-based mycologic methods.

Different treatment options for this infection are available since no standard treatment has been defined. Small, isolated lesions may be successfully treated by simple surgical excision ${ }^{14}$ or cryosurgery. ${ }^{2}$ Multiple and larger lesions usually require systemic antimycotic therapy. On occasion, a combination of surgical and systemic antinfungal agents has proved efficacious. ${ }^{7,16}$ Itraconazole is the most commonly used drug, followed by amphotericin B. ${ }^{3-5,9}$ Itraconazole doses used range between 100 and $400 \mathrm{mg}$ for 2-8 months in monotherapy regimens. ${ }^{3,6,7}$

This case report is remarkable due to its clinical presentation with multiple nodules and vegetating tumours as well as the slow but successful response to monotherapy with high-dose itraconazole. Furthermore, it illustrated the efficacy of molecular techniques in Alternaria species identification.

\section{Conflict of interest}

The authors have nothing to declare.

\section{References}

1. Andersen B, Sørensen JL, Nielsen KF, Gerrits van den Ende B, de Hoog S. A polyphasic approach to the taxonomy of the Alternaria infectoria species-group. Fungal Genet Biol. 2009;46:642-56.

2. Ara M, Aspiroz C, Zaballos P, Alvarez R, Rezusta A, Giménez JA. Relapse of cutaneous Alternaria infectoria in a renal transplant recipient after 2 years. Acta Derm Venereol. 2006;86:154-5.

3. Brasch J, Busch JO, de Hoog GS. Cutaneous phaeohyphomycosis caused by Alternaria infectoria. Acta Derm Venereol. 2008;88:160-1.

4. Dubois D, Pihet M, Clec'h CL, Croué A, Beguin H, Bouchara JP, et al Cutaneous phaeohyphomycosis due to Alternaria infectoria. Mycopathologia. 2005;160:117-23.

5. Gallelli B, Viviani M, Nebuloni M, Marzano AV, Pozzi C, Messa P, et al Skin infection due to Alternaria species in kidney allograft recipients: report of a new case and review of the literature. J Nephrol. 2006;19: 668-72.

6. Gerdsen R, Uerlich M, De Hoog GS, Bieber T, Horré R. Sporotrichoid phaeohyphomycosis due to Alternaria infectoria. Br J Dermatol. 2001;145: 484-6.

7. Gilaberte M, Bartralot R, Torres JM, Reus FS, Rodríguez V, Alomar A, et al. Cutaneous alternariosis in transplant recipients: clinicopathologic review of 9 cases. J Am Acad Dermatol. 2005;52:653-9.

8. Guerin V, Barbaud A, Duquenne M, Contet-Audonneau N, Amiot F, Ortega F, et al. Cushing's disease and cutaneous alternariosis. Arch Intern Med. 1991;151:1865-8.

9. Halaby T, Boots H, Vermeulen A, van der Ven A, Beguin $\mathrm{H}$, van Hooff $\mathrm{H}$, et al. Phaeohyphomycosis caused by Alternaria infectoria in a renal transplant recipient. J Clin Microbiol. 2001;39:1952-5.

10. Ioannidou D, Maraki S, Krüger Krasagakis S, Stefanidou M, Krasagakis K, Alexandrakis $M$, et al. Cutaneous alternariosis revealing acute myeloid leukaemia in an adult patient. Mycoses. 2004;47:227-30.

11. Laumaillé C, Le Gall F, Degeilh B, Guého E, Huerre M. Cutaneous Alternaria infectoria infection after liver transplantation. Ann Pathol. 1998;18: 192-4.

12. Lo Cascio G, Ligozzi M, Maccacaro L, Fontana R. Utility of molecular identification in opportunistic mycotic infections: a case of cutaneous Alternaria infectoria infection in a cardiac transplant recipient. J Clin Microbiol. 2004;42:5334-6.

13. Lyke KE, Miller NS, Towne L, Merz WG. A case of cutaneous ulcerative alternariosis: rare association with diabetes mellitus and unusual failure of itraconazole treatment. Clin Infect Dis. 2001;32:1178-87.

14. Nulens E, De Laere E, Vandevelde H, Hilbrands LB, Rijs AJ, Melchers WJ, et al Alternaria infectoria phaeohyphomycosis in a renal transplant patient. Med Mycol. 2006;44:379-82.

15. Porto E, Martins JE, Heins-Vaccari E. Feo-Hifomicoses. In: Porto E, Martins JE Heins-Vaccari E, et al., editors. Tratado de Micologia Médica. São Paulo: Sarvier; 2002. p. 519-61.

16. Segner S, Jouret F, Durant JF, Marot L, Kanaan N. Cutaneous infection by Alternaria infectoria in a renal transplant patient. Transpl Infect Dis. 2009;11:330-2.

17. Sood N, Gugnani HC, Guarro J, Paliwal-Joshi A, Vijayan VK. Subcutaneous phaeohyphomycosis caused by Alternaria alternata in an immunocompetent patient. Int J Dermatol. 2007;46:412-3.

18. Vieira R, Veloso J, Afonso A, Rodrigues A. Cutaneous alternariosis in a liver transplant recipient. Rev Iberoam Micol. 2006;23:107-9. 